\title{
SOCIAL HISTORY
}

DOI: 10.46340/ephd.2020.6.4.7

\section{Oksana Shportun}

ORCID ID: https://orcid.org/0000-0003-4528-4329

Andrii Tabachuk

ORCID ID: https://orcid.org/0000-0003-1261-5056

Central Ukrainian National Technical University, Kropyvnytskyi, Ukraine

\section{ABUSE OF AUTHORITY AND CORRUPTION CRIMES OF OFFICIALS OF FINANCIAL INSTITUTIONS FROM THE DNIEPER UKRAINE (XVIII - XIX CENTURIES)}

\author{
Оксана Шпортун, \\ Андрій Табачук \\ Центральноукраїнський національний технічний університет, Кропивницький, \\ Україна
}

\section{ЗЛОВЖИВАННЯ СЛУЖБОВИМ СТАНОВИЩЕМ ТА КОРУПЦЙНІ ЗЛОЧИНИ ЧИНОВНИКІВ ФІНАНСОВИХ УСТАНОВ НАДДНІПРЯНСЬКОЇ УКРАЇНИ (XVIII - XIX CT.)}

The article is devoted to the analysis of abuses of authority of officials of financial institutions of Dnieper Ukraine (XVIII - XIX centuries).

The article describes the structure of the administration of the Russian Empire, defines the main criteria for the position of civil servant. Analysis of the legislation of the Russian Empire shows the government's efforts to stimulate and control the work of officials.

Based on the analysis of archival documents (the vast majority of which are introduced for the first time into scientific circulation) examples of crimes against the state are given: inaction, incompetence, corruption, bribery, official activities for profit; negligent disposal of state property and resources, etc.

It was established that the actions of the state authorities to prevent corruption, abuse and inaction of civil servants were ineffective, as evidenced by constant complaints, public outrage and abuse of power by officials, who were forced to attract public attention through publications in the press. As a result, the abuse of power by officials of financial institutions negatively affected citizens' trust in the government and destroyed the mechanism of public administration from within.

Keywords: abuse of power, corruption, bribery, inaction of the authorities, the Russian Empire, the State Chamber, a financial institution, Dnieper Ukraine, an official, civil service.

3 розвитком демократичного суспільства, забезпечення прав, свобод та інтересів людини становлять основний пріорітет для держави, яка в свою чергу, виступає гарантом соціальноекономічної безпеки громадян. Саме на державне управління покладено обов'язок забезпечувати та відстоювати «життя і здоров’я, честь і гідність, недоторканність і безпеку»1 кожного громадянина.

\footnotetext{
${ }^{1}$ Конститучія України, 1996 (Верховна Рада України) Офіційний сайт Верховної Ради України $<$ https://zakon.rada.gov.ua/laws/show/254к/96-вр\#Text>. (2020, листопад, 12).
} 
Держава реалізовує свої повноваження через побудований механізм управління та органів влади, здійснює контроль за загальнодержавними, міжнародними, особовими справами. Задля реалізації своїх функцій, створюються державні органи, які в сукупності становлять структуру держави.

Ключовим у реалізації зовнішньої та внутрішньої політики $є$ безпека. Захищеність національних інтересів та своєчасне виявлення, запобігання, ліквідація потенційних загроз є основними складовими національної безпеки. Держава у свою чергу повинна здійснювати усі можливі заходи для забезпечення свободи, соціально-економічної безпеки, удосконалювати механізм реалізації державного управління, уникаючи ризиків та загроз. Бездіяльність, корумпованість та зловживання владою у корисливих цілях вважаються діями, що нівелюють розвиток громадянського суспільства, знищують авторитет та довіру до органів державної влади, а також становлять загрозу національній безпеці.

Проблеми зловживання владою, корумпованості практично повністю нівелюють довіру до влади та знищують принципи демократії. Нині - це гостра проблема більшості країн світу. Проте не можна не згадати про корупційний досвід минулого, зокрема Російської імперії, де головним був єдиний правлячий уряд, а державна влада, незважаючи на принципи доброчесності та справедливості, використовувалася у корисливих цілях чиновників.

Тож, слід розглянути найпоширеніші випадки зловживань службовим становищем та оцінити надслідки бездіяльності, халатності чиновництва минулого з метою недопущення та врахування негативних моментів у майбутньому.

Проблеми функціонування державних органів влади, зокрема фінансових установ Російської імперії є об'єктом дослідження вітчизняних та зарубіжних дослідників.

Діяльність органів місцевого самоврядування, бюджетної політики фінансових установ Російської імперії досліджували Головко О. ${ }^{1}$, Жвалюк В. ${ }^{2}$, Черемісін О. ${ }^{3}$, Коріненко П. ${ }^{4}$

Проблеми реалізації фіскальної політики уряду Російської імперії та ії негативний вплив на грошову систему досліджувала Орлик С. ${ }^{5}$ ÏI публікації розкривають проблеми роботи уряду стосовно стабілізації фінансового стану держави у кризовій ситуації, а також причини затримки розвитку системи оподаткування.

Структуру, порядок проходження державної служби, випадки зловживання владою чиновників та відповідальність за службове недбальство досліджували Шандра В. ${ }^{6}$, Бармак M. ${ }^{7}$

Монографія Орлика В. ${ }^{8}$ надає комплексну характеристику фінансової системи Російської імперії, вказуючи на проблемні моменти у роботі державних фінансових установ. У публікаціях ${ }^{9,10}$ вчений детально розглянув роботу чиновників фінансових установ, та проаналізував їх взаємодію з урядом. Також Орлик В. неодноразово вказував на недоліки у роботі державної служби та надав оцінку фінансової політики уряду Російської імперії.

Питання запобігання корупції губернської чиновницької адміністрації в Надніпрянській

\footnotetext{
${ }^{1}$ Головко, О. (2010). Податкові присутствія як суб’єкти фінансово-управлінської діяльності на українських землях у складі Російської імперії. Право і безпека: Науковий журнал, 4, 34.

2 Жвалюк, В. (2001). Податкові органи Російської імперї в Украӥні у другій половині ХІХ - на початку ХХ ст.: організаційно-правові засади діяльності. Київ: Атіка, 161.

3 Черемісін, О. (2017). Міське самоврядування крізь призму регіонального розвитку. Херсон: Олді-плюс, 582.

${ }^{4}$ Коріненко, В. Терещенко, П. (2006). Проблеми державного кредитного забезпечення поміщицьких та селянських господарств в роки Столипінської аграрної реформи. Український селянин (10), 29-32. <http://nbuv.gov.ua/UJRN/Ukrsel_2006_10_9>(2020, листопад, 20).

${ }^{5}$ Орлик, С. (2012). До питання реалізації фіскальної політики уряду земськими інституціями українських губерній Російської імперії. NOWA UKRAINA, 12, 5-13; Орлик, С. (2013). Вплив фінансових реформ на курс рубля у 60-х роках XIX століття в Російській імперії. Наукові записки з української історії, 33, $259-261$.

${ }^{6}$ Шандра, В. (2005). Генерал-губернаторства в Україні: XIX-початок XX сm. Київ, 427.

${ }^{7}$ Бармак, М. (2016). Формування російської імперської системи державної служби на українських землях (XVIII - XIX). Тернопіль: Астон, 392.

${ }^{8}$ Орлик, В. (2007). Податкова політика Російської імперії в Україні в дореформений період, Кіровоград: Імекс-ЛТД, 503.

${ }_{9}^{9}$ Орлик, В. (2012). Проблема достовірності статистичних даних в дослідженнях питань економічної історії Російської імперії. Слисавет. Збірник наукових працьь Кіровоградського національного технічного університету. Історичні науки. Кіровоград: КНТУ, 1, 171-177.

${ }^{10}$ Орлик В. (2004). Органи фінансового управління Російської імперії в Україні (кінець XVIII - середина XIX ст.). Проблеми історії Украӥни XIX-початку XX cm. (VII). К.: Ін-т історії України НАН України. С.75-81.
} 
Україні розглянув Ярошенко М. Дослідник у своїх публікаціях проаналізував основні заходи імперської влади для запобігання корупції серед губернських службовців та наголошував, що «незважаючи на зростання кількості чиновницького апарату, його професійний рівень залишався досить низьким, а його погана організація сприяла подальшому зростанню різного роду зловживань і хабарництву» ${ }^{1}$.

Проблеми органів місцевого самоврядування, зокрема корумпованості чиновників та службового недбальства розкрив Желізняк В. У дисертаційній роботі ${ }^{2}$ дослідник вивчав проблеми зловживань службовим становищем представників муніципальних органів та методи боротьби 3 неправомірними діями чиновників з метою забезпечення державних фінансових інтересів.

Заслуговує на увагу публікація Орлика В. у співавторстві з Орлик С. Автори статті акцентували увагу на найбільш складних теоретико-методологічних та джерелознавчих проблемах економічної історії України. Вчені наголошують на кооперації науковців різних галузей знань у дослідженнях з економічної історії України, що значно «розширить перспективи таких досліджень і уможливить отримання нових знань» ${ }^{3}$.

Дослідженням роботи фінансових установ Російської імперії на українських землях також займалися Шевчук Б. ${ }^{4}$, Годунова Л. ${ }^{5}$, Демешко Ю. ${ }^{6}$, Кучерявенко М. ${ }^{7}$ У той же час питання зловживань владою чиновників фінансових установ та заходів щодо їх уникнення $\epsilon$ малодослідженими та потребують подальшого вивчення.

Мета статті дослідити та охарактеризувати основні проблеми механізму державного імперського управління стосовно службового недбальства у фінансових установах Наддніпрянської України XVIII-XIX ст. Розглянути основні види неправомірних дій чиновників та способів уникнення зловживань владою. Проаналізувати ефективність дій державної влади щодо запобігань корупції, зловживань та бездіяльності державних службовців.

Зловживання владою, корупція в Україні та світі - $\epsilon$ широко розповсюдженим явищем, яке охопило всю вертикаль влади та негативно впливає на прийняття державно-управлінських рішень, тим самим гальмуючи розвиток економічного зростання та демократії. Ці проблеми є не новими для державного менеджмента, адже виникли з появою фінансових та владних взаємовідносин і прямо впливають на стан суспільства.

До переходу під управління царату українське суспільство мало власну чітко організовану систему виборної державної влади. Але включення Правобережної України до складу Російської імперії спричинило розповсюдження бюрократичної форми організації державного управління. Оскільки імперська державна влада базувалася на принципах абсолютизму, практично нівелюючи засади демократії, чиновники ставали панівною верствою населення. Нерідко серед державних управлінських структур траплялися випадки бездіяльності, службового недбальства, хабарництва та здирства.

Структура державного управління Російської імперії була складною та розгалуженою. Запроваджений У 1722 році «Табель про ранги...» ${ }^{8}$ був єдиною законодавчою основою здійснення державної та військової служби. Державна служба складалася з трьох категорій чиновників: цивільна

\footnotetext{
${ }^{1}$ Ярошенко, М. (2016). Запобігання корупції в системі губернської адміністрації в Наддніпрянській Україні (друга половина XIX - початок XX ст.). Науковий вісник Ужгородського наиіонального університету. Серія: Право, $36(1), 35$.

${ }^{2}$ Желізняк, В. (2013). Губернатор в системі місцевого управління Російської імперії 1796-1914рp.

(на матеріалах Волинської губернії): дисертаиія на здобуття наукового ступеню кандидата історичних наук. Тернопіль: Тернопільський національний педагогічний університет ім. В. Гнатюка, 229.

${ }^{3}$ Орлик, В., Орлик, С. (2019). Теоретико-методологічні та джерелознавчі проблеми економічної історії України. Універсум історії та археології, 2 (27), 2, 5.

${ }^{4}$ Шевчук, Б. (2011). Законодавче врегулювання роботи Контрольного відділення Волинської казенної палати і механізми реалізації його повноважень у першій половині XIX ст. Суспільно-політичні прочеси на украӥнських землях: історія, проблеми, перспективи: зб. матеріалів Всеукр. наук.-практ. конф., 168-171.

${ }^{5}$ Годунова, Л. (2014). Украӥнські землі в податковій політиці Росї (XVIII- початок XX cm.): історіографія : дисертація на здобуття наукового ступеню кандидата історичних наук. Кіровоград: Кіровоградський національний технічний університет, 237.

${ }^{6}$ Демешко, Ю. (2014). Участь купецтва в реалізації імперського управління в Південній Україні в дореформений період: дисертаиія на здобуття наукового ступеню кандидата історичних наук. Переяслав-Хмельницький: ДВНЗ «Переяслав-Хмельницький Державний Педагогічний Університет імені Григорія Сковороди», 20.

${ }^{7}$ Кучерявенко, М. (2002). Генезис податкового регулювання. Харків: Легас, 1, 1, 665.

8 Полное собрание законов Российской империи (1831). Собрание 1. Санкт-Петербург, 3890.
} 
(статська), військова (яка включала військову службу в армії та флоті) та придворна служби. Всього існувало 14 рангів державних службовців, кожному з яких відповідали посади та вказувалися строки перебування на посаді. «Табель про ранги...» ${ }^{1}$ слугував ніби путівником просуванню чиновників про кар'єрних східцях та формував накопичення досвіду та професіоналізму. Він містить перелік рангів та посад цивільної служби, до якої належали фінансові установи та управління державними маєтностями (Таблиця 1).

Таблиця 1

Перелік рангів та посад цивільної служби, до якої належали фінансові установи та управління державними маєтностями (витяг 3 «Табелю про ранги...»

\begin{tabular}{|l|l|}
\hline Клас & \\
\hline I & канцлер \\
\hline II & дійсний таємний радник \\
\hline III & таємний радник служба \\
\hline IV & дійсний статський радник \\
\hline V & статський радник \\
\hline VI & колезький радник, військовий радник \\
\hline VII & надвірний радник \\
\hline VIII & колезький асесор \\
\hline IX & титулярний радник \\
\hline X & колезький секретар \\
\hline XI & корабельний секретар \\
\hline XII & губернський секретар \\
\hline XIII & провінційний секретар \\
\hline XIV & колезький реєстратор \\
\hline
\end{tabular}

Джерело: Полное собрание законов Российской империи (1831). Собрание 1. Спб., № 3890, 486-489.

Згідно із «Статутом про службу цивільну»² при прийомі на державну службу брали до уваги соціальний стан, походження, вік та знання осіб, що претендували на посаду. Зарахування на певну посаду здійснювалося двома шляхами: при безпосередньому прийнятті на державну службу та зміни посади.

До всіх осіб, які перебували на державній службі застосовували такі моральні критерії:

- здоровий глузд;

- добра воля в виконанні доручених справ;

- людинолюбство або ж гуманізм;

- вірність службі та державі;

- завзятість до загального добра;

- чесність, безкорисність та утримання від хабарів;

- рівний та справедливий суд незалежно від соціального стану;

- обов'язок захищати невинних та скорботних ${ }^{3}$.

Держава покладала обов'язок здійснювати службу відповідно до присяги, з наполегливістю та згідно чинного законодавства, не допускаючи корисливості та хабарництва. Кожен службовець присягав «верно и нелицемерно служить и во всем повиноваться... по совести своей исправлять, и для своей корысти, свойства, дружбы и вражды, противно должности своей и присяги не поступать, и таким образом себя вести и поступать, как и верному Его Императорского Величества подданному благопристойно есть и надлежит...» ${ }^{4}$ Сам текст присяги містив морально-юридичний зміст. Вірність,

\footnotetext{
1 Там само.

${ }^{2}$ Свод уставов (1842). О службе гражданской. Санкт-Петербург.

${ }^{3}$ Там само.

${ }^{4}$ Свод Уставов (1895). О службе гражданской. Москва: 378-379.
} 
чесність, безкорисливість - все це моральні принципи, які були закладені у роботу службовців. Юридичний зміст присяги полягав у дотриманні указів імператора та вірності державі.

Невиконання або неналежне виконання посадових обов'язків, перевищення владних повноважень, хабарництво вважалися діями, які паплюжать чиновника та державу та носили суворе покарання. Згідно 3 «Генеральним регламентом» ${ }^{1}$ за хабарництво застосовували найвищу міру покарання - смертну кару або довічне позбавлення волі.

Разом з наділенням широкими владними та фінансовими повноваженнями, держава створила цілу систему контролю та відповідальності за службові порушення. Бездіяльність чиновників у вирішенні державних справ спонукала уряд до посилення контролю за їх роботою. Так, Бармак М. зауважив, що «у 1767 р. Сенат своєю ухвалою підкреслив необхідність інформування всіма державними установами про отримання урядових указів, про хід їх реалізації та кінцеве виконання. Службовці колегій, канцелярій і контор зобов'язувалися вирішувати справи згідно із «точною силою та розумом законів», «неупереджено і без зволікання», а також у визначені терміни. Якщо вирішення справ затягувалося через «нехтування, лінощі і недбалість», то за кожен згаяний день із виконавців стягувався штраф, причому залежно від термінів його сума могла зростати удвічі і втричі» ${ }^{2}$. Таким чином, уряд намагався боротися із бездіяльністю та халатністю у роботі державних службовців шляхом адміністративного примусу.

Уряд був незадоволений частими зловживаннями владою державних службовців, про що свідчить іменний указ імператора «О воспрещении взяток и посулов за оное» ${ }^{3}$, я якому зазначалося, що дії чиновників, пов'язані з незаконним підкупом у власних корисливих цілях, вважалися «лихоїмством», або ж, хабарництвом. Згодом основні положення указу увійшли до «Уложення про покарання кримінальних та виправних» ${ }^{4}$ - нормативного акту Російської імперії, що визначав поняття злочину та проступку, учасників правопорушень, родів, ступенів та наслідків покарань. Окремий розділ «Уложення...» визначає особливі покарання і проступки у державній службі.

«Уложення про покарання кримінальних та виправних» 1845 p. трактує перевищення службових повноважень як:

- дії, які виходять за рамки посадових обов’язків всупереч чинному законодавству;

- будь-які дії без дозволу вищого керівництва;

- самовільне вирішення справ, не маючи на це право 5

Протизаконною вважалася бездіяльність чиновників, а саме, коли не застосовувалися дозволені законом засоби, з метою попередження або призупинення будь-якого зловживання, яке могло б загрожувати державній цілісності та суспільству.

Покарання за бездіяльність або перевищення службових повноважень в залежності від міри скоєного правопорушення були у вигляді:

- зауваження або догани;

- відсторонення від посади;

- звільнення з державної служби;

- переміщення з вищої посади на нижчу;

- відрахування строку служби;

- позбавлення волі;

- в особливих випадках, позбавлення усіх привілеїв та звань з відсилкою на проживання

в Томській або Тобольській губерніях на строк від 1 до 2 років» ${ }^{6}$.

Уряд постійно намагався контролювати та запобігати злодіянням у державній службі. Так, у 1885 році було змінено «Уложення про покарання кримінальних та виправних». Новий «кримінальний кодекс» Російської імперії визначав хабарництво («лихоїмство») як «прийняття

\footnotetext{
1 Лебедев, В.И. (сост.) (1937). Генеральний регламент. Москва: Гос.соц.-эк.изд-во. Исторический факультет Московского государственного университета имени М.В.Ломоносова <http://www.hist.msu.ru/ER/Etext/general.htm> (2020, листопад, 20).

2 Бармак, М. (2016). Формування російської імперської системи державної служби на украӥнських землях (XVIII-XIX). Тернопіль: Астон, 191.

${ }^{3}$ Полное собрание законов Российской империи (1830). Собрание 1. Санкт-Петербург, 2871.

${ }^{4}$ Уложение о наказаниях уголовных и исправительных. (1845). Санкт-Петербург, 920.

${ }^{5}$ Там само.

${ }^{6}$ Шпортун, О. Табачук, А. (2020). Перевищення влади та службових повноважень чиновниками казенних палат Надніпрянської України (XVIII-XIX ст.). Історія, археологія, інформаційна, бібліотечна та архівна справа: актуальні проблеми науки та освіти: тези доповідей I Міжнародної наукової конференції, 36-37.
} 
подарунків чиновників у грошовій, речовій або інших формах, які приймали за справи або дії, що стосувалися службової діяльності. Прийняття подарунків, або ж коштів, обіцяних за вчинення службової діяльності чиновником не в межах його компетенції вважалося шахрайством»1 .

Вищою мірою хабарництва вважалося здирництво, тобто:

-будь-який прибуток або винагорода, отримана через тиск, погрози або через страх притиснення;

-будь-яке вимагання подарунків або вигоди, внаслідок надання послуг, що стосуються службової діяльності;

- будь-які побори у грошовій та матеріальній формах, які не установленні законом;

- незаконний примус до роботи».

Згідно «Укладення про покарання» Бармак В. виділяє такі види посадових злочинів:

- «невиконання указів, розпоряджень, законів і інших законних вимог по службі;

- перевищення влади, скасування узаконень, прийняття рішень всупереч закону, протизаконна

бездіяльність влади, перевищення службових повноважень;

- недбале зберігання або управління казенним майном;

- фальсифікації документів по службі;

- хабарництво і лихварство;

- неправосуддя;

- порушення встановлених правил при вступі на посаду і залишення посади;

- недбалість у здійсненні посадових обов'язків;

- порушення обов'язку підлеглості по службі;

- порушення порядку при призначенні на службу, на посаду і при звільненні» ${ }^{2}$.

Незважаючи на численні застереження у вигляді адміністративної та кримінальної відповідальності за бездіяльність та зловживання владою, корумпованість та халатність чиновників залишалася головною проблемою державної влади. Фінансові установи на місцях нерідко займалися привласненням бюджетних коштів, траплялися випадки використання фінансових ресурсів не за призначенням ${ }^{3}$. Нерідко казенні палати робили неправильні обчислення при нарахуванні податей та зборів, про що свідчать скарги стосовно надмірних податків та тиску збоку органів муніципальної влади. Так, до казенної палати надійшла скарга Добровольського 3. та Крижанівського Д. стосовно утиску Чигиринського міщанського суспільства та надмірного обкладання податками ${ }^{4}$. Неправильні розрахунки казенних палат з одного боку, негативно впливали на довіру до влади та обурювали населення, з іншого боку - виникали проблеми в дослідженні фінансового стану Російської імперії в цілому. На проблеми у бюджетній сфері Російської імперії, особливо у веденні обліку фінансових операцій вказував Орлик В.: «відсутні точні розрахунки видаткової частини, особливо це стосувалося військового відомства й імператорського двору. Єдиною статтею, що була обрахована з точністю до рублів, були видатки на училища, виховні будинки, лікарні й штатні пенсії. Усі інші цифри, як правило, округлялися до мільйонів рублів, що свідчить про досить приблизні підрахунки й підгонку їх під дохідну частину» 5 .

Привласнення бюджетних коштів було поширеним зловживанням серед посадовців різного рівня. У 1829 році у м. Слисаветграді Катеринославського намісництва широкого суспільного розголосу набула справа викрадення коштів з бюджету міським головою Пашутіним Я. Створена міською думою незалежна комісія нарахувала збитків на суму 6600 руб. ${ }^{6}$ Того ж року в Слисаветградській міській думі розглядали справу про викрадення коштів херсонського повітового стряпчого, який поцупив із сундука нижнього земського суду бюджетні кошти․

\footnotetext{
${ }^{1}$ Шпортун, О. Табачук, А. (2020). Перевищення влади та службових повноважень чиновниками казенних палат Надніпрянської України (XVIII-XIX ст.). Історія, археологія, інформаційна, бібліотечна та архівна справа: актуальні проблеми науки та освіти: тези доповідей I Міжнародної наукової конференції, 36-37.

${ }^{2}$ Бармак, М. (2016). Формування російської імперської системи державної служби на українських землях (XVIII-XIX). Тернопіль: Астон, 224.

3 Державний архів Київської області. ф. 280. on. 175. спр. 366 a, арк. 16-16 зв.

${ }^{4}$ Державний архів Київської області. ф. 280. on. 45. сnр.19.

5 Орлик, В. (2008). Податкова політика уряду Російської імперії в кінці XVIII-середині XIX ст.: дисертація на здобуття наукового ступеню доктора історичних наук. Переяслав-Хмельницький: ДВНЗ «ПереяславХмельницький Державний Педагогічний Університет імені Григорія Сковороди», 19.

${ }^{6}$ Державний архів Кіровоградської області. ф. 18. on. 1. сnр. 215, арк. 427-432 зв.

${ }^{7}$ Державний архів Кіровоградської області. ф. 18. on. 1. сnр. 131, арк. 469-469 зв.
} 
Слід зауважити, що більшою мірою до кримінальної відповідальності притягувалися чиновники нижчого рівня та майже повністю відсутні відомості про корупцію та зловживання службовим становищем серед високопосадовців. Тривалий час законодавчих основ щодо притягнення до відповідальності міністрів, членів Державної Ради та генерал-губернаторів не існувало. «Про необхідність запровадження відповідальності та контролю за діяльністю міністерств зазначав Сперанський М. у «Плані загального державного устрою» (1809), «Положення про Державну Раду» (1810)» .

Неправомірні дії посадовців оскаржувалися у відповідних установах, органах місцевого самоврядування та у судовому порядку. Іноді населення було наскільки обурене зловживання владою та нахабством чиновників, що змушені були привертати увагу громадськості шляхом публікацій в пресі ${ }^{2}$.

Поширеним явищем серед чиновників було взаємне покривання та «тісна співпраця» 3 поліцією. У записці про зловживання владою у м. Богуславі, графиня Браницька скаржилась на беззаконня 3 боку нового городничого, який не реагував на незаконний продаж горілки канцеляристом Богуславського повітового суду ${ }^{3}$.

Досить часто до губернських правлінь надходили скарги щодо бездіяльності поліції стосовно зловживань колишніх чиновників, з проханням вищого керівництва посприяти у вирішенні питання неправомірного здирства з населення як у грошовій, так і в натуральній формі. У матеріалах Київського губернського правління міститься колективне звернення жителів єврейського містечка Катеринополя 3 проханням розібратися із зловживаннями колишнього чиновника - засідателя Звенигородського нижнього земського суду Мачуговського, котрий вимагав від євреїв плату за дозвіл на будівництво або ремонт у сумі 100 руб. асигнаціями або 360 кг яловичини та 3 пуда свічок ${ }^{4}$.

Недбалість, бездіяльність, нахабне ставлення, особливо «представниками сільських громадських адміністрацій та членами органів міського самоврядування при зборі податей. Негативним явищем був формалізм фінансових установ щодо волосних та сільських збирачів податків. Казначейства не завжди чітко дотримувались інструкційних матеріалів, не забезпечували міські й сільські товариства податковою документацією» ${ }^{5}$.

Відсторонення від посади або звільнення було однією з м'яких мір покарань державних службовців за неправомірні дії під час проходження державної служби. Досить часто звільнення, незважаючи на наявність підтверджених фактів зловживань, оскаржувалися в судовому порядку. Чиновники поновлювалися на посаді та продовжували «служити» державі. Так, у 1835 р. був зафіксований факт недбалості уздійсненні посадових обов'язків. до Київського губернського правління надійшла скарга на чиновника відділу відкупних справ Вінницького земського суду Я. Пєньковським, щодо незаконної видачі ярликів на провезення винна. За такий проступок його було звільнено з посади ${ }^{6}$.

Згодом, Я. Пєньковський заперечував корисливі мотиви та оскаржив своє звільнення, стверджуючи, що здійснював видачу ярликів на провезення винна не знаючи своїх посадових обов'язків та владних повноважень. Чиновника було поновлено на державну службу у Вінницькій міській поліції.

Отже, намагання уряду Російської імперії здійснювати контроль за всіма державними справами спричинило появу ієрархічної структури управління та зростанню бюрократичного апарату. Державна влада будувалася на принципах єдиноначальності та вимагала високого рівня компетентності та моральності від державних службовців, адже від них залежали результати роботи державного апарату управління. Структура державного управління Російської імперії була складною та розгалуженою. Систематизація чинів була побудована за ієрархічним принципом та складалася

\footnotetext{
${ }^{1}$ Бармак, М. (2016). Формування російської імперської системи державної служби на українських землях (XVIII-XIX). Тернопіль: Астон. 95.

${ }^{2}$ Центральний державний історичний архів України в м. Києві, ф. 442. on.1. сnp. 382.

${ }^{3}$ Шпортун, О. Табачук, А. (2020). Зловживання службовим становищем чиновників Наддніпрянської України к. XVIII-поч. XX ст. Forum Numizmatyczne: Studia i Materiaty, 4, 78.

${ }^{4}$ Центральний державний історичний архів України в м. Києві, ф. 533. on.5. cnp. 1203, арк. 16-17.

${ }^{5}$ Орлик, В. (2008). Податкова політика уряду Російської імперії в кінці XVIII-середині XIX ст.: дисертація на здобуття наукового ступеню доктора історичних наук. Переяслав-Хмельницький: ДВНЗ «ПереяславХмельницький Державний Педагогічний Університет імені Григорія Сковороди», 19.

${ }^{6}$ Центральний державний історичний архів України в м. Києві, ф. 442. on.1. сnр. 1952. арк. 1-20.

${ }^{7}$ Центральний державний історичний архів України в м. Києві, ф. 442. on.1. спр. 1952. арк. 22-22 з8.
} 
iз 14 класів, кожному з яких наділялися певні повноваження. Чиновники нижчого класу (рангу) повинні були підпорядковуватися вищестоящим.

Держава намагалася стимулювати та контролювати роботу державних службовців акцентуючи на принципах моральності та юридичної відповідальності, за вчинення порушень та злодіянь. Незважаючи на високі вимоги до кандидатів на посаду державного службовця, владні повноваження та управління фінансами нерідко спокушали до злочинів та бездіяльності. Серед поширених зловживань владою слід відмітити: бездіяльність та формалізм; некомпетентність та малоосвіченість, що породжувала низку інших проблем у роботі бюрократичного апарату; корупція, хабарництво та вчинення службової діяльності з метою наживи; недбале розпорядження державним майном та ресурсами та ін. Всі ці проблеми негативно впливали на довіру громадян до уряду та руйнували механізм державного управління зсередини.

\section{References:}

1. Barmak, M. (2016). Formuvannia rosiiskoi imperskoi systemy derzhavnoi sluzhby na ukrainskykh zemliakh (XVIII-XIX) [Formation of the Russian imperial system of civil service on the Ukrainian lands (XVIII-XIX)]. Ternopil: Aston. [in Ukrainian].

2. Lebedev V. I. (comp.) (1937). Generalniy reglament [General Regulations]. Moscow: State Social and Economic Publishing House. Istoricheskiy fakultet Moskovskogo gosudarstvennogo universiteta imeni [Faculty of History, Lomonosov Moscow State University]. <http://www.hist.msu.ru/ER/Etext/general.htm> (2020, November, 20). [in Russian].

3. Holovko, O. (2010). Podatkovi prysutstviia yak subiekty finansovo-upravlinskoi diialnosti na ukrainskykh zemliakh u skladi Rosiiskoi imperii. [Tax Representation as subjects of financial and management activity on Ukrainian lands within the Russian Empire]. Pravo i bezpeka [Law and security], 4. 32-37. [in Ukrainian].

4. Hodunova, L. (2014). Ukrayinski zemli v podatkoviy politytsi Rosiyi (XVIII-pochatok XX st.: Historiography): istoriohrafiya [Ukrainian lands in the tax policy of Russia (XVIII-early twentieth century.)]: dysertatsiya na zdobuttya naukovoho stupenyu kandydata istorychnykh nauk [Dissertation for the degree of candidate of historical sciences]. Kirovograd: Kirovograd National Technical University. [in Ukrainian].

5. Derzhavnyi arkhiv Kirovohradskoi oblasti [State Archives of Kirovohrad region], f. 18, op. 1, spr. 215; f. 18, op. 1, spr. 131. [in Ukrainian].

6. Derzhavnyi arkhiv Kyivskoi oblasti [State Archives of Kyiv region], f. 280, op. 175, spr. 336 a;. f280, op. 45, spr. 19. [in Ukrainian].

7. Demeshko, Yu. (2014). Uchast kupetstva v realizatsiyi imperskoho upravlinnya $v$ Pivdenniy Ukrayini $v$ doreformenyy period [Participation of merchants in the implementation of imperial rule in southern Ukraine in the pre-reform period:]: dysertatsiya na zdobuttya naukovoho stupenyu kandydata istorychnykh nauk [Dissertation for the degree of candidate of historical sciences]. Pereyaslav-Khmelnytsky: Pereyaslav-Khmelnytsky State Pedagogical University named after Hryhoriy Skovoroda [in Ukrainian].

8. Zhvaliuk, V. (2001). Podatkovi orhany Rosiiskoi imperii v Ukraini u druhii polovyni XIX-na pochatku XX st.: orhanizatsiino-pravovi zasady diialnosti [Tax authorities of the Russian Empire in Ukraine in the second half of the nineteenth and early twentieth centuries: organizational and legal principles of activity]. Kyiv: Atika. [in Ukrainian].

9. Zheliznyak, V. (2013). Hubernator v systemi mistsevoho upravlinnya Rosiyskoyi imperiyi 1796-1914 rr. (na materialakh Volynskoyi huberniyi) [Governor in the system of local government of the Russian Empire in 1796-1914 (on the materials of the Volyn province)]: dysertatsiya na zdobuttya naukovoho stupenyu kandydata istorychnykh nauk [Dissertation for the degree of candidate of historical sciences. Ternopil: Ternopil National Pedagogical University. V. Hnatyuk. [in Ukrainian].

10. Konstytutsiya Ukrayiny, 1996 (Verkhovna Rada Ukrayiny) [Constitution of Ukraine, 1996 (Verkhovna Rada of Ukraine)] <https://zakon.rada.gov.ua/laws/show/254k/96-vr\#Text>.]. Ofitsiynyy sayt Verkhovnoyi Rady Ukrayiny [Official site of the Verkhovna Rada of Ukraine] <https://zakon.rada.gov.ua/laws/show/254k/96-vr\#Text>. (2020, November, 12). [in Ukrainian].

11. Korinenko, V. Tereshchenko, P. (2006). Problemy derzhavnoho kredytnoho zabezpechennia pomishchytskykh ta selianskykh hospodarstv v roky Stolypinskoi ahrarnoi reformy [Problems of state credit security of landowners and peasants in the years of Stolypin agrarian reform. Ukrainian Peasant]. Ukrainskyi selianyn [Ukrainian peasant], 10, 29-32. 〈http://nbuv.gov.ua/UJRN/Ukrsel_2006_10_9>. (2020, November, 20). [in Ukrainian].

12. Kucheriavenko, M. (2002). Henezys podatkovoho rehuliuvannia [Genesis of tax regulation]. Kharkiv: Lehas, 1, 1. [in Ukrainian].

13. Orlyk, V. (2008). Metodolohichni aspekty doslidzhennia problem podatkovoi polityky v ukrainskykh guberniiakh Rosiiskoi imperii u pershii polovyni XIX st. [Methodological aspects of the study of tax policy problems in the Ukrainian provinces of the Russian Empire in the first half of the XIX century]. Ukrainskyi istorychnyi zhurnal. [Ukrainian historical journal], 5, 187-195. [in Ukrainian]. 
14. Orlyk, V., Orlyk, S. (2019). Teoretyko-metodolohichni ta dzhereloznavchi problemy ekonomichnoi istorii Ukrainy. [Theoretical-methodological and source-studying problems of the Economic history of Ukraine]. Universum istorii ta arkheolohii [Universe of history and archeology], 2, 5-27. [in Ukrainian].

15. Orlyk, V. (2004). Orhany finansovoho upravlinnia Rosiiskoi imperii v Ukraini (kinets XVIII - seredyna XIX st.). [Bodies of financial management of the Russian Empire in Ukraine (end of the 18th - the middle of the 19th century)]. Problemy istorii Ukrainy XIX-poch. XX st. [Problems of the history of Ukraine in the 19th century-early 20th century], 7, 75-81. [in Ukrainian].

16. Orlyk, V. (2007). Podatkova polityka Rosiiskoi imperii v Ukraini v doreformenyi period [Tax policy of the Russian Empire in Ukraine in the pre-reform period]. Kirovohrad: Imeks LTD. [in Ukrainian].

17. Orlyk, V. (2008). Podatkova polityka uryadu Rosiys'koyi imperiyi v kintsi XVIII-seredyni XIX st. [Tax policy of the government of the Russian Empire in the late XVIII-mid XIX centuries]: dysertatsiya na zdobuttya naukovoho stupenyu doktora istorychnykh nauk [Dissertation for the degree of Doctor of Historical Sciences]. PereyaslavKhmelnytsky: Pereyaslav-Khmelnytsky State Pedagogical University named after Hryhoriy Skovoroda.

18. Orlyk, V. (2012). Problema dostovirnosti statystychnykh danykh v doslidzhenniakh pytan ekonomichnoi istorii Rosiiskoi imperii. [The problem of reliability of statistics in studies of economic history of the Russian Empire]. Zbirnyk naukovykh prats Kirovohradskoho natsionalnoho tekhnichnoho universytetu. Istorychni nauky. [Collection of scientific works of Kirovograd National Technical University. Historical sciences], 1, 171-177.

19. Orlyk, S. (2012). Do pytannia realizatsii fiskalnoi polityky uriadu zemskymy instytutsiiamy ukrainskykh hubernii Rosiiskoi imperii [On the issue of the government's fiscal policy implementation by the Zemsky Institutions of the Ukrainian provinces of the Russian Empire]. NOWA UKRAINE. [New Ukraine], 12, 5-13. [in Ukrainian].

20. Orlyk, S. (2013). Vplyv finansovykh reform na kurs rublia u 60-kh rokakh XIX stolittia v Rosiiskii imperii. [The impact of financial reforms on the ruble in the 60s of the XIX century in the Russian Empire]. Naukovi zapysky z ukrainskoi istorii. [Scientific notes on Ukrainian history], 33, 259-261. [in Ukrainian].

21. Polnoe sobranie zakonov Rossiyskoy imperii [The complete collection of the laws of the Russian Empire]. Sobranie 1. Spb., 1830 [in Russian].

22. Svod Ustavov (1845). [Body of Statutes (1845)]. O sluzhbe hrazhdanskoi [Civil Service Charters]. SPb. [in Russian].

23. Svod Ustavov (1895). [Body of Statutes (1845)]. O sluzhbe hrazhdanskoi [Civil Service Charters]. SPb. [in Russian].

24. Ulozhenie o nakazaniyah ugolovnyih $i$ ispravitelnyih (1845) [Code of law about criminal and correctional punishments (1845)]. SPb. [in Russian].

25. Tsentralnyi derzhavnyi istorychnyi arkhiv Ukrainy [Central State Historical Archive of Ukraine], f. 442, op. 1, spr. 382; f. 442, op. 1, spr. 1203; f. 442, op. 1, spr. 1952. [in Ukrainian].

26. Cheremisin, O. (2017). Miske samovriaduvannia kriz pryzmu rehionalnoho rozvytku [Municipal self-government through the prism of regional development]. Kherson: Oldi-plius. [in Ukrainian].

27. Shandra, V. (2005). Heneral-hubernatorstva v Ukraini: XIX-pochatok XX st. [Governor General in Ukraine: XIX - early twentieth century]. Kyiv. [in Ukrainian].

28. Shevchuk, B. (2011). Zakonodavche vrehuliuvannia roboty Kontrolnoho viddilennia Volynskoi kazennoi palaty I mekhanizmy realizatsii yoho povnovazhen u pershii polovyni XIX st. [Legislative regulation of the Control Department of the Volyn State Chamber and mechanisms for the exercise of its powers in the first half of the nineteenth century]. Suspilno-politychni protsesy na ukrainskykh zemliakh: istoriia, problemy, perspektyvy: zb. materialiv Vseukr. nauk.-prakt. konf. [Socio-political processes in the Ukrainian lands: history, problems, prospects. Collection of materials of the All-Ukrainian scientific-practical conference], 168-171. [in Ukrainian].

29. Shportun, O. Tabachuk, A. (2020). Zlovzhyvannia sluzhbovym stanovyshchem chynovnykiv Naddniprianskoi Ukrainy k. XVIII - poch. XIX st. [Abuse of the official opinion of the officials of the adventures of the adventures in the Dniper Ukraine (18-early 20 cent.)]. Forum Numizmatyczne: Studia i Materiaty. [Numismatic Forum: Studies and Materials], 4, 69-78. [in Ukrainian].

30. Shportun, O. Tabachuk, A. (2020). Perevyshchennia vlady ta sluzhbovykh povnovazhen chynovnykamy kazennykh palat Nadniprianskoi Ukrainy (XVIII-XIX st.). [Abuse of power and official authority by officials of the state chambers of Dnieper Ukraine (XVIII-XIX centuries)]. Istoriia, arkheolohiia, informatsiina, bibliotechna ta arkhivna sprava: aktualni problemy nauky ta osvity: tezy dopovidei I Mizhnarodnoi naukovoi konferentsii, Kropyvnytskyi [History, archeology, information, library and archival affairs: current issues of science and education: I International science conference, Kropyvnytsky], 35-38. [in Ukrainian].

31. Iaroshenko, M. (2016). Zapobihannia koruptsii v systemi hubernskoi administratsii v Naddniprianskii Ukraini (druha polovyna XIX - pochatok XX st.). [Prevention of corruption in the system of the provincial administration in the Dnieper Ukraine (second half of the XIX - the beginning of XX century)]. Naukovyi visnyk Uzhhorodskoho natsionalnoho universytetu [Scientific Bulletin of Uzhhorod National University], 36 (1), 33-36. [in Ukrainian]. 